\title{
TERMIKUSAN TESZTELT GENERÁTOR ÁLLÓRÉSZEK HENGERESSÉGÉNEK VIZSGÁLATA
}

\author{
Ferencsik Viktória \\ egyetemi tanársegéd, Miskolci Egyetem, Gyártástudományi Intézet \\ 3515 Miskolc, Miskolc-Egyetemváros, e-mail: ferencsik.viktoria@uni-miskolc.hu \\ Varga Gyula \\ egyetemi docens, Miskolci Egyetem, Gyártástudományi Intézet \\ 3515 Miskolc, Miskolc-Egyetemváros, e-mail: gyula.varga@uni-miskolc.hu
}

\begin{abstract}
Absztrakt
A tanulmány a generátor állórészek belső alakhibájának vizsgálatával foglalkozik, melyet magas és alacsony hömérsékleten való tesztelési eljárás idéz elö. Ez a fajta meghibásodás befolyásolhatja a generátorok megfelelö müködését, mivel a generátor egy másik alkatrészének, a rotornak a forgása során rezgések léphetnek fel. Kijelenthetö, hogy ennek a hibának a hatása csökkenti a generátor teljesítményét. A publikáció célja annak vizsgálata, hogy a különbözö tesztelési paraméterek úgy, mint hömérséklet, tesztelési idö, az állórész el van-e látva rezgéscsillapitó gyürüvel vagy sem, milyen hatással birnak. A kisérlet megtervezéséhez és végrehajtásához a teljes faktoriális kísérlettervezés módszerét alkalmaztuk. Az egyes elemek hengerességének mérése Taylor Hobson Talyrond 365 gyártmányú köralak- és helyzethiba-méröberendezésen valósult meg. A mért adatokból speciális viszonyszámokat alkottunk, annak érdekében, hogy meghatározzuk azt a paramétertartományt, mely a legnagyobb mértékü deformációt okozza.
\end{abstract}

Kulcsszavak: generátor, faktoriális kísérlettervezés, klimatikus vizsgálat, alakhelyesség, 3D diagram

\begin{abstract}
This paper investigates the internal shape correctness of alternator stators which is caused by high and low temperature storage test. This kind of failure can affect the adequate operation of alternators since vibrations can occur during rotation of the other part of the alternator, the rotor. It can be stated that the effects of this error reduce the efficiency of the alternator. The aim of this study is to examine the influence of different testing parameters, such as the temperature and the running time of the test and that the stator is equipped with damping element or not. To planning and executing the experiments we use full factorial experimental design method. The measurement of the cylindricity of the specimens was done with a circular and position error measuring machine type Taylor Hobson Talyrond 365. From the measured data, special improvement ratios can be calculated in order to define the appropriate range of testing parameters which results greater deformity.
\end{abstract}

Keywords: Alternator, factorial experimental design, climatic test, shape correctness, 3D diagram

\section{Bevezetés}

Manapság a személygépjárművek egyre több elektromos és elektronikai eszközzel vannak ellátva a nagyobb biztonság és kényelem érdekében [1,2]. Ezeknek az eszközöknek a müködése általában a jármü akkumulátorával valósul meg, melynek folyamatos töltést biztosít a generátor, vagyis az a forgó 
villamos berendezés, amely a tengelyükön bevezetett mechanikai energiát villamos energiává alakítja [3].

A generátor felépítését tekintve áll egy gerjesztett forgórészből és egy egy-vagy többfázisú tekercsrendszerrel ellátott állórészből, melyet „statornak” is nevezünk. Az állórész csapágypajzsai, illetve az abban elhelyezett csapágyak tartják középpontban a forgórészt, biztosítva annak sima és stabil futását (1. ábra).

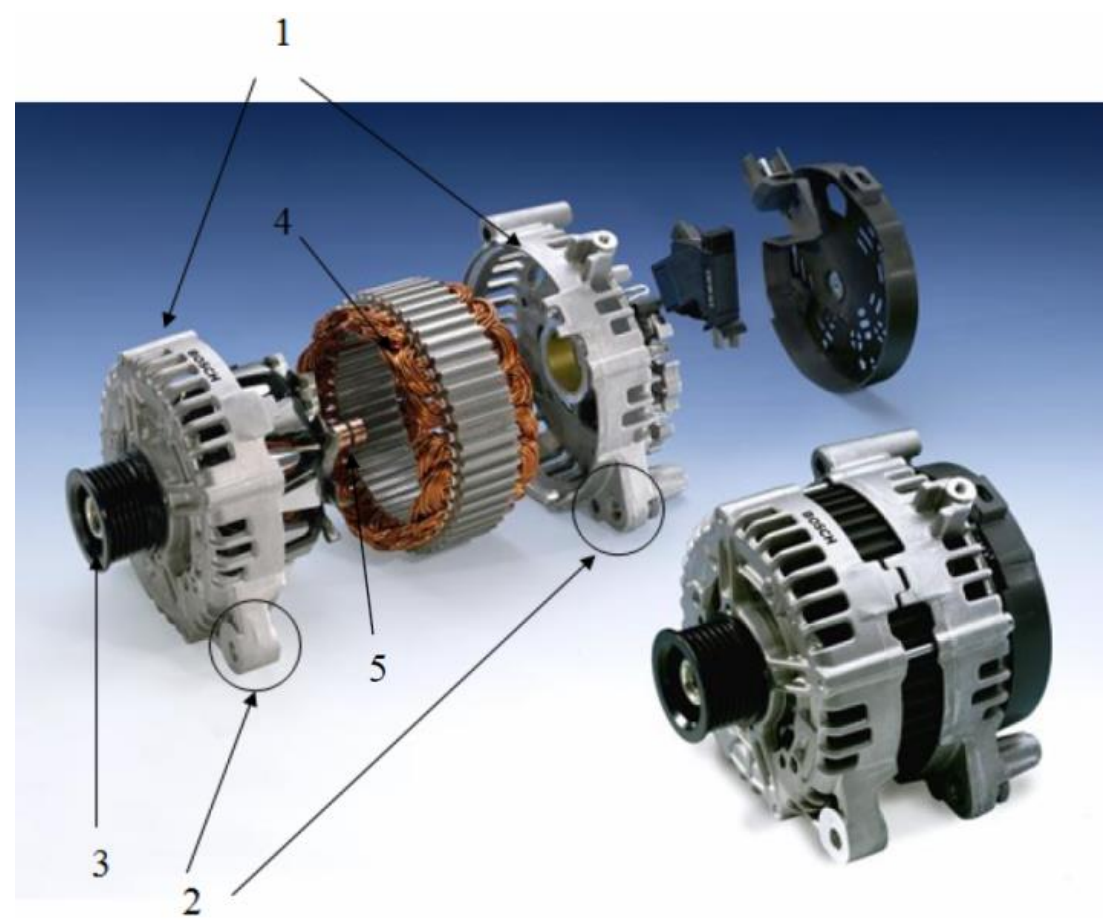

1. ábra A generátor részei. [4]

1. Első és hátsó pajzs, 2. szerelési (felfogató) fülek, 3. ékszíjtárcsa, 4. stator tekercselése, 5. forgórész

Tehát a gerjesztett forgórészt mechanikai energiával forgatják a generátor tengelyére csatlakozó valamilyen erőgéppel és ennek következtében a forgórész indukcióvonalai metszik az állórész tekercsrendszerét, melynek hatására feszültség jön létre. Az indukált feszültség frekvenciája függ a rotor sebességétől, így ha a rotor nem képes adott sebességgel forogni az állórész nem megfelelő hengeressége miatt, akkor csökken a teljesítmény, ráadásul rezgéseket és zajt is generál.

A gyártók nagy hangsúlyt fektetnek a különböző tesztelési eljárások elvégzésére, jelen tanulmány célja pedig az volt, hogy vizsgálat alá vonjuk a generátor-állórész hengerességi hibáját, melyet alacsony és magas hőmérsékleten tartottak adott tesztelési módszernek megfelelően. A kutatómunkához felhasználtuk a teljes faktoriális kísérlettervezés módszerét [5,6], mely a bemenő paraméterek maximuma és minimuma között érvényes. Jelen kísérletben, elsősorban tesztelési folyamat beállítható értékei alapján, a hőmérsékletet $(\mathrm{T})$, a teszt futási idejét (t) és a zajcsillapító gumigyürü (GGY) meglétét határoztuk meg bemenő paraméterként, ez utóbbi a hátsó csapágypajzs és az állórész között helyezkedik el. 


\section{Kísérleti körülmények}

\subsection{Alkalmazott kísérlettervezési módszer}

A kísérlet megtervezéséhez és végrehajtásához a teljes faktoriális kísérlettervezés módszerét választottuk, melynek alapmodellje a 2. ábrán látható

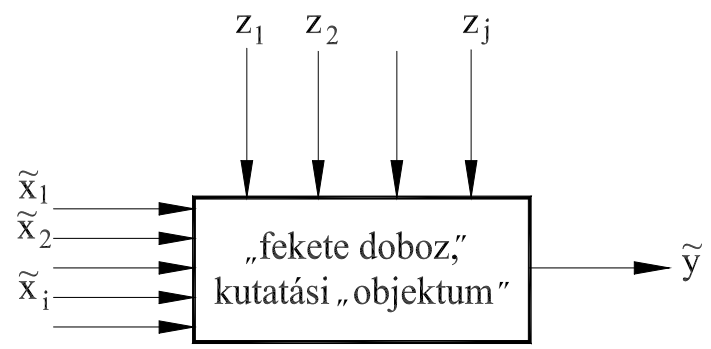

\section{2. ábra A kísérlettervezés alapmodellje. [6]}

A cél a függő változó ( $\widetilde{\mathrm{y}}$ ) és a független változók $\left(\widetilde{\mathrm{x}}_{\mathrm{i}}\right)$ közötti függvénykapcsolat meghatározása. Mindegyik független változó, vagyis faktor több értéket vehet fel, melyeket szinteknek nevezünk.

Jelen kísérletben faktorként a tesztelési hőmérsékletet $(T)$, időtartamot $(t)$ és a zajcsillapító gumigyürüvel való ellátottságot (GGY) vizsgáltuk, értékeiket a kísérlettervezési módszernek megfelelően 2 szintre állítottuk be, egy adott ipari szabványban [7] meghatározottak szerint, ezt foglalja össze az alábbi táblázat.

1. táblázat. Beállitott kísérleti paraméterek

\begin{tabular}{|c|c|c|c|c|c|c|}
\hline \multirow{2}{*}{ Ssz. } & \multicolumn{3}{|c|}{ Tesztparaméterek } & \multicolumn{3}{c|}{ Transzformált paraméterek } \\
\cline { 2 - 7 } & $\mathrm{T}\left[{ }^{\circ} \mathrm{C}\right]$ & $\mathrm{t}[\mathrm{h}]$ & Gumigyürü (GGY) & $\mathrm{x}_{1}$ & $\mathrm{x}_{2}$ & $\mathrm{x}_{3}$ \\
\hline 1 & -40 & 150 & nincs & -1 & -1 & -1 \\
\hline 2 & 130 & 150 & nincs & +1 & -1 & -1 \\
\hline 3 & -40 & 300 & nincs & -1 & +1 & -1 \\
\hline 4 & 130 & 300 & nincs & +1 & +1 & -1 \\
\hline 5 & -40 & 150 & van & -1 & -1 & +1 \\
\hline 6 & 130 & 150 & van & +1 & -1 & +1 \\
\hline 7 & -40 & 300 & van & -1 & +1 & +1 \\
\hline 8 & 130 & 300 & van & +1 & +1 & +1 \\
\hline
\end{tabular}

Vizsgálataink során a hengeresség változásának szemléletesebbé tételéhez létrehoztunk egy dimenzió nélküli viszonyszámot, melyet az alábbi képletek alapján számítottunk ki:

$$
\begin{gathered}
\rho_{C Y L}=\frac{C Y L_{u t \text { tána }}}{C Y L_{\text {elótte }}} \\
\rho \%=(\rho-1) \cdot 100 \%
\end{gathered}
$$


ahol:

$\rho_{C Y L} \quad$ A különböző hengerességi paraméterek javulási dimenzió nélküli viszonyszáma, mely a termikus teszt hatására bekövetkező változásokat mutatja

$C Y L_{\text {utána }} \quad$ A termikusan tesztelt statorok hengeressége

$C Y L_{\text {elótte }} \quad$ A statorok hengeressége a termikus tesztet megelőzően

$\rho \% \quad$ Az eltérés százalékos értéke

Minél kisebb $\rho_{C Y L}$ értéke, annál nagyobb a javulás mértéke.

\subsection{A tesztelési folyamat}

Az elemzés tárgyához tartozó tesztmódszer célja annak vizsgálata, hogy az adott alkatrész alkalmas-e alacsony $\left(-40^{\circ} \mathrm{C}\right)$ és magas hömérsékleten $\left(130^{\circ} \mathrm{C}\right)$ való tartásra, valamint üzemeltetésre, anélkül, hogy az egyes felületelemeken törés, felkeményedés, stb. keletkezne.

A magas és alacsony hőmérsékleten való tárolási vizsgálat egy álló kivitelű Weiss WK1 180 gyártmányú klimatikus tesztkamrában lett végrehajtva, melynek hőmérséklettartománya $-40^{\circ} \mathrm{C}$ és $+180^{\circ} \mathrm{C}$ között terjed. A berendezés tartalmaz egy szabadalmaztatott klíma- és hőmérsékletkondicionáló rendszert, melynek segítségével a melegítés és hütés sebességét egyaránt $4{ }^{\circ} \mathrm{C} /$ perc értékre állítottuk be.

Az egyes pajzsokkal összeszerelt állapotban lévő statorok elhelyezése vízszintesen történt a kamrában, annak érdekében, hogy elkerüljük a darab saját súlyából származó esetlegesen fellépő deformációkat.

\subsection{A hengeresség mérése}

$\mathrm{Az}$ állórészek hengerességének mérése a Miskolci Egyetem Gyártástudományi Intézetébe telepített Taylor Hobson Talyrond 365 gyártmányú köralak- és helyzethiba mérőberendezésen történt, melynek alapfunkciói közé tartozik a tengelyre merőleges metszetbeli hibák feltárásakor a forgó munkadarabon a kívánt függőleges helyzetben rögzített mérőelemmel történő profilletapogatás. Ez a funkció alkalmas (többek között) a köralak és hengerességi hiba feltárására, kiértékelésére [8]. A hengerességet úgy értékeli, hogy kombinál egy bizonyos számú körkörösségi mérést, melyeket a vizsgálandó darabok különböző magasságaiban mért, jelen kísérletnél $30 \mathrm{~mm}$-es mérési tartományban $2 \mathrm{~mm}$-ként végeztük el mérést, tehát 16 mérési sík összehasonlítása történt $\mu$ m-es pontossággal.

Viszont, ahogy azt már ismertettük, az állórészeket a védőpajzsokkal összeszerelve vizsgáltuk, azonban a belső hengeres felület elemzéséhez szükséges volt egy adott átméröjü furat forgácsolására az első pajzson, a tapintófej megfelelő hozzáférése érdekében, ezt szemlélteti a 3. ábra. 


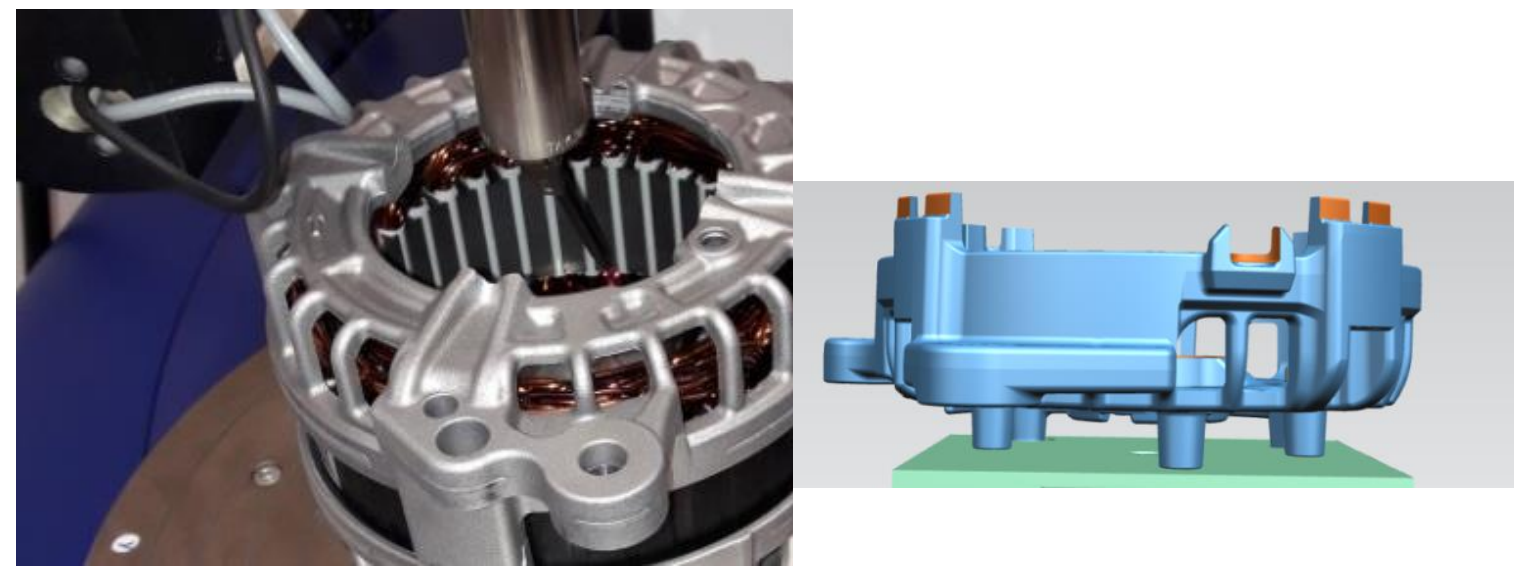

\section{3. ábra Mérési pozíció}

Továbbá, szükség volt egy rögzítő készülék tervezésére (4. ábra) is, mivel az alkatrész geometriájából adódóan azt nem tudtunk vízszintesen elhelyezni a mérőberendezés asztalán, pedig ez elengedhetetlen a sikeres mérési folyamathoz, hiszen a mérendő darab és a tapintó forgástengelyének egybe kell esnie, mely adott türéssel megvalósítható a berendezés saját szoftverének segítségével.

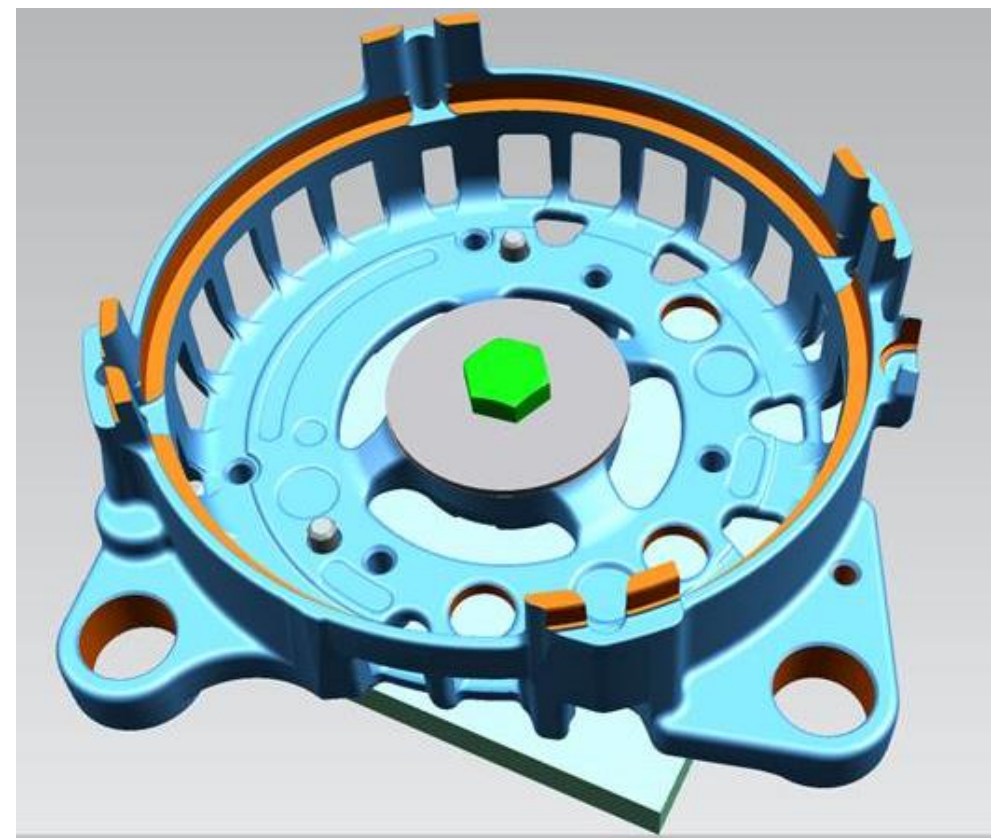

\section{4. ábra A pozícionáló készülék modellje}

Mivel a generátor állórész belső felülete lamelláris szerkezetü, tehát nem alkot összefüggő köralakot, így elengedhetetlen volt a mért eredmények utólagos analizálása ahhoz, hogy kiszürjük a geometriából adódó tévesen hengerességi hibaként detektált felületelemeket, ahogyan azt az 5. ábra szemlélteti. 


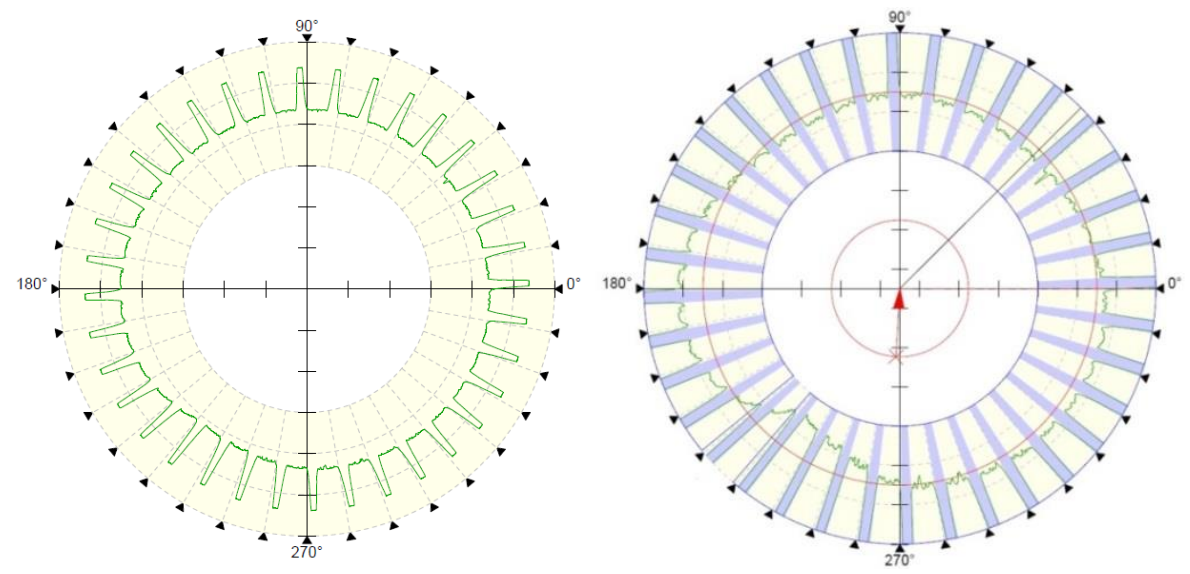

5. ábra Köralak-helyesség analizis elött (bal) és után (jobb)

A hengerességet jellemző paraméterek közül a müködési tulajdonságokat leginkább befolyásoló 4 jellemzőt vettük figyelembe, melyek:

- CYLp: az anyag legnagyobb eltérése csúcsok (peak) formájában referenciahengerhez viszonyítva

- CYLv: az anyag legnagyobb eltérése bemélyedések (valley) formájában referenciahengerhez viszonyítva

- CYLt: a kiemelkedések és árkok összegzett távolsága

- CYLtt: a kúposság mértéke [8]

A hengeresség teljes jellemzéséhez szükséges a mért értékek 3D-s ábrázolása is, melyre példaként a 6. ábra a 4-es számmal jelölt generátor állórész alakhelyességének változását mutatja.
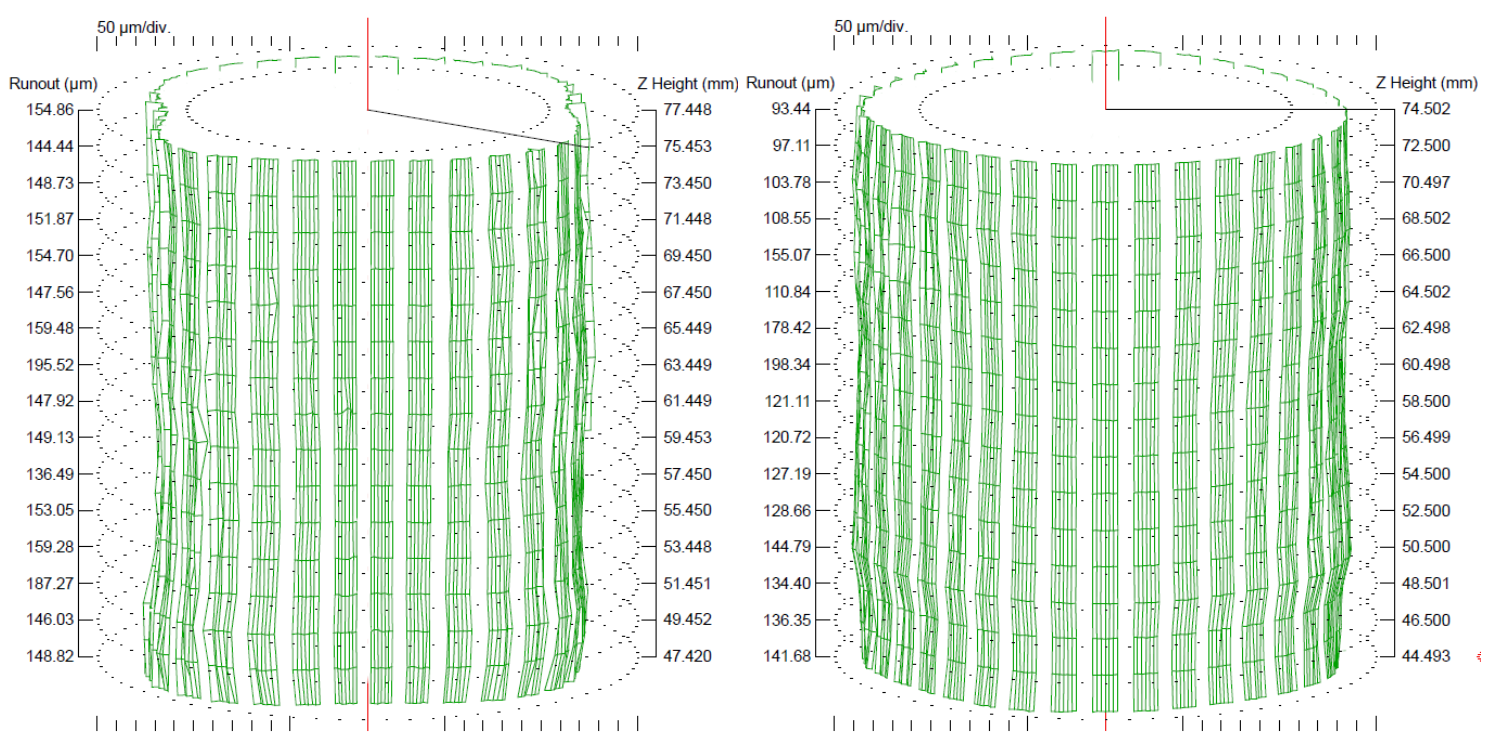

6. ábra Köralak-helyesség szerelt (bal) és termikusan tesztelt (jobb) állapotban 
Ahogy az egyértelmúen látható, szerelt állapotban az állórész négyzetes alapot vesz fel, melynek számszerủ értékét eddig nem határozták meg, viszont magának a jelenségnek a kialakulását korábban is feltételezték. Ennek oka, hogy az első és hátsó csapágypajzsok szerelése mechanikusan oldható csavaros kötéssel valósul meg, adott nyomatékkal, 4-4,6 Nm, való meghúzással, mely torzítja a darab köralak-helyességét. Javaslatot tettünk a nyomaték 3-3,5 Nm-re való csökkentésére és további vizsgálatok elvégzésére, hiszen a hengerességén felül ez a módosítás hatással lehet a generátor további jellemzőire, funkcióira és teljes egészének működésére.

\section{Eredmények}

A termikus teszt megvalósítása előtt és után is elvégeztük a generátor állórészek belső hengerességének mérését, majd meghatároztuk az (1-2) képletek alapján az egyes viszonyszámok értékeit, ezt foglalja össze a 2. táblázat.

2. táblázat. A mért hengerességi paraméterek és számított viszonyszámok

\begin{tabular}{|c|c|c|c|c|c|c|}
\hline \multirow{2}{*}{ Ssz. } & \multicolumn{2}{|c|}{ CYLp $[\mu \mathrm{m}]$} & \multirow{2}{*}{$\begin{array}{c}\rho_{\text {CYLp }} \\
{[\%]}\end{array}$} & \multicolumn{2}{|c|}{ CYLv $[\mu \mathrm{m}]$} & \multirow{2}{*}{$\begin{array}{c}\rho_{C Y L v} \\
{[\%]} \\
\end{array}$} \\
\hline & Szerelt & Tesztelt & & Szerelt & Tesztelt & \\
\hline 1 & 101,78 & 94,25 & $-7,39$ & 150,81 & 146,06 & $-3,15$ \\
\hline 2 & 116,71 & 107,62 & $-7,79$ & 112,70 & 191,38 & 69,81 \\
\hline 3 & 79,08 & 123,36 & $-55,99$ & 87,71 & 114,84 & 30,93 \\
\hline 4 & 113,97 & 132,56 & 16,31 & 116,23 & 85,84 & $-26,15$ \\
\hline 5 & 294,73 & 93,27 & $-66,45$ & 155,11 & 129,22 & $-16,69$ \\
\hline 6 & 342,20 & 54,42 & $-84,09$ & 101,83 & 77,44 & $-23,95$ \\
\hline 7 & 323,66 & 108,58 & $-66,45$ & 125,08 & 70,39 & $-43,72$ \\
\hline 8 & 66,53 & 67,88 & 2,03 & 149,87 & 113,14 & $-24,51$ \\
\hline \multirow{2}{*}{ Ssz. } & \multicolumn{2}{|c|}{ CYLt $[\mu \mathrm{m}]$} & & \multicolumn{2}{|c|}{ CYLtt $[\mu \mathrm{m}]$} & \\
\hline & Szerelt & Tesztelt & {$[\%]$} & Szerelt & Tesztelt & {$[\%]$} \\
\hline 1 & 252,59 & 240,31 & $-4,86$ & $-177,20$ & 212,87 & $-220,13$ \\
\hline 2 & 229,42 & 299,01 & 30,33 & 157,83 & 266,24 & 68,69 \\
\hline 3 & 166,79 & 238,20 & 42,81 & 49,32 & 85,73 & 73,82 \\
\hline 4 & 230,20 & 218,40 & $-5,13$ & 84,27 & 135,92 & 61,29 \\
\hline 5 & 449,83 & 222,50 & $-50,54$ & 241,35 & $-195,43$ & $-180,97$ \\
\hline 6 & 444,03 & 131,86 & $-70,30$ & $-159,26$ & 76,21 & $-147,85$ \\
\hline 7 & 448,74 & 178,96 & $-60,12$ & $-296,11$ & $-147,00$ & $-50,36$ \\
\hline 8 & 216,39 & 181,01 & $-16,35$ & $-207,73$ & $-169,85$ & $-18,24$ \\
\hline
\end{tabular}

A teljes faktoriális kísérlettervezés módszerének alkalmazásával empirikus formulákat (3-6 egyenletek) alkottunk, majd a MathCAD 15.0 program segítségével az eredményeket axonometrikus ábrák formájában is demonstráljuk (7-8. ábra). 

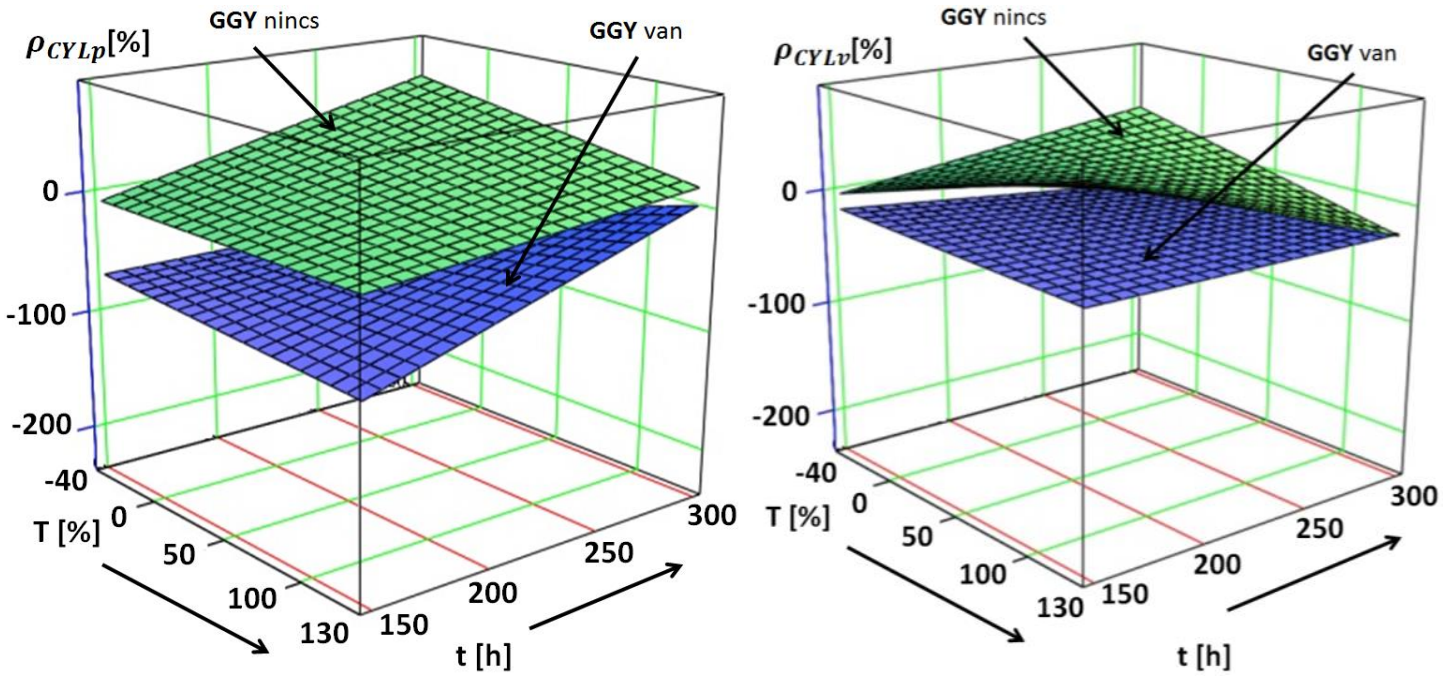

7. ábra A hengeresség változása a kiemelkedések (bal) és bemélyedések (jobb) szempontjából

$$
\begin{aligned}
\rho_{C Y L_{p}}= & -77,709-0,18 \cdot T+0,253 \cdot t-16,065 \cdot G G Y+8,81 \cdot 10^{-4} \cdot T \cdot t-0,409 \cdot T \cdot G G Y- \\
& -0,108 \cdot t \cdot G G Y++2,422 \cdot 10^{-3} \cdot T \cdot t \cdot G G Y \\
\rho_{C Y L_{v}}= & 6,469+0,498 \cdot T-0,058 \cdot t-4,066 \cdot G G Y-2,031 \cdot 10^{-3} T \cdot t-0,696 \cdot T \cdot G G Y- \\
& -0,081 \cdot t \cdot G G Y++3,069 \cdot 10^{-3} \cdot T \cdot t \cdot G G Y
\end{aligned}
$$
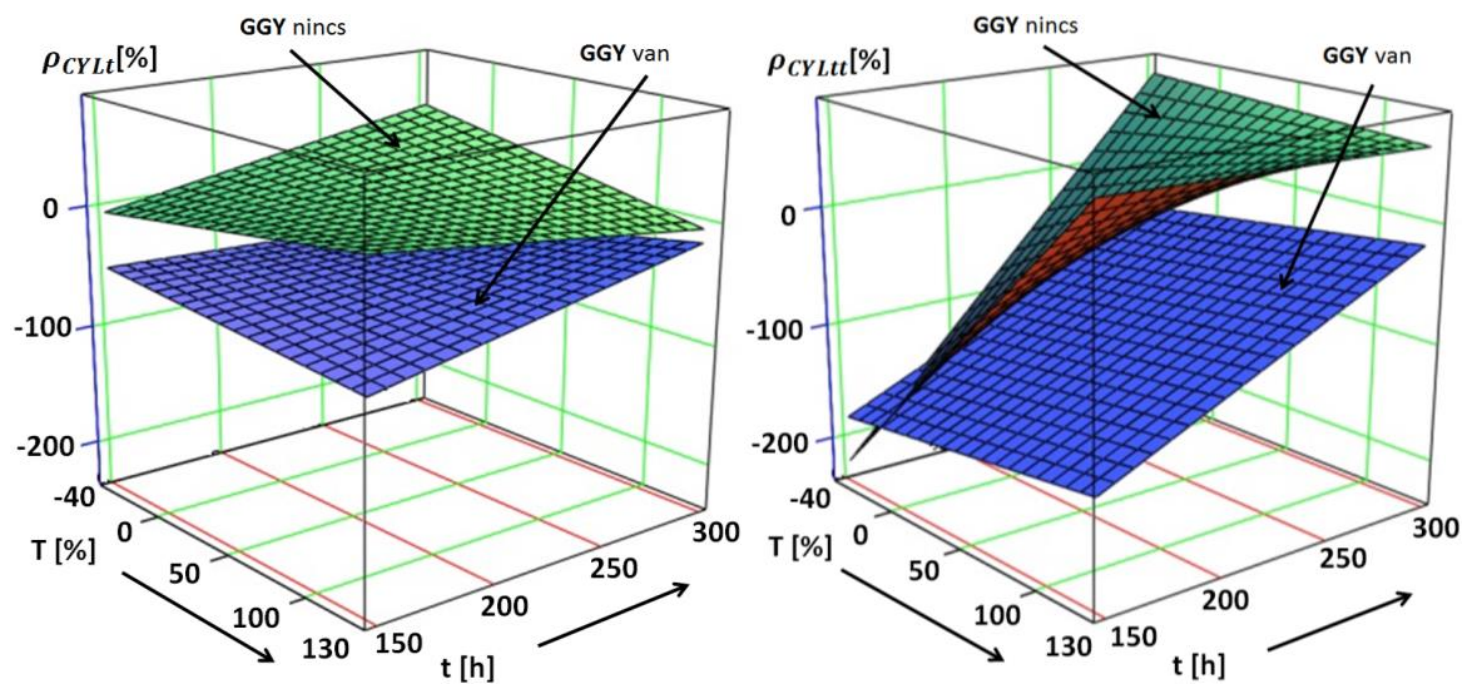

8. ábra $A$ hengeresség változása a legnagyobb eltérések (bal) és kúposság (jobb) szempontjából 


$$
\begin{aligned}
\rho_{C Y L_{t}}= & -42,626+0,103 \cdot T+0,112 \cdot t-17,936 \cdot G G Y-3,841 \cdot 10^{-4} \cdot T \cdot t-0,593 \cdot T \cdot \\
& G G Y-0,076 \cdot t \cdot G G Y+2,876 \cdot 10^{-3} \cdot T \cdot t \cdot G G Y \\
\rho_{C Y L_{t t}}= & -339,149+1,841 \cdot T++1,177 \cdot t+35,597 \cdot G G Y-5,948 \cdot 10^{-3} \cdot T \cdot t-1,641 \cdot T \cdot \\
& G G Y-0,308 \cdot t \cdot G G Y++5,909 \cdot 10^{-3} \cdot T \cdot t \cdot G G Y
\end{aligned}
$$

\section{4. Összefoglalás}

A cikk egy személygépjármü alkatrész, a generátor állórész belső hengeres felületének kísérleti vizsgálatával foglalkozik, melyet termikus tesztnek vetettek alá passzív, tehát müködtetés nélküli üzemmódban. Kísérleti paraméterként szerepelt a tesztelési hőmérséklet $(T)$, a teszt futtatási ideje ( $\mathrm{t}$ ), valamint az, hogy az egyes darabok el vannak-e látva zajcsillapító gumigyürüvel (GGY) vagy sem.

A kísérlet célja az volt, hogy meghatározzuk, ezek a paraméterek hogyan befolyásolják a köralakhelyesség változását, illetve egymással milyen korrelációban állnak. Felhasználtuk a teljes faktoriális kísérlettervezés módszerét, a különböző hengerességet jellemző paraméterek mért és analizált értékeiből kiszámoltuk - az általunk megalkotott formulák szerint - a dimenzió nélküli viszonyszámokat, majd az empirikus képletek felírását követően 3D-s ábrák segítségével is bemutattuk az eredményeket, melyek alapján a következő állításokat tesszük:

- A leggyakrabban használt hengerességet jellemző paraméterhez, a CYLt eredményeihez kapcsolódó axonometrikus ábrák nagymértékben azonosak a CYLp értékeihez tartozóhoz, tehát az alakhiba egészét a felület kiemelkedései alkotják,

- A számszerủ és ábrázolt eredmények alapján is egyértelmüen kijelenthető, hogy a zajcsillapító gumigyürü alkalmazásának pozitív hatása van

- A hengeresség legnagyobb eltéréseinek szempontjából a legkedvezőbb eredmény a magas hőmérséklet és rövidebb ciklusidő beállításával alakult ki, azonban a kúposság nézőpontjából az alacsony hőmérséklet alkalmazása okozott pozitív változást, mindezek magyarázatául az állórész gyártása során kialakuló, majd a szerelés, termikus teszt során megváltozó feszültségviszonyok szolgálnak, ennek a jelenségnek a további elemzése is tárgyát képezi jövőbeli kutatómunkánknak.

\section{Köszönetnyilvánítás}

A kutató munka az Európai Unió és a magyar állam támogatásával, az Európai Regionális Fejlesztési Alap társfinanszírozásával, a GINOP-2.3.4-15-2016-00004 projekt keretében valósult meg, a felsőoktatás és az ipar együttmüködésének elösegítése céljából.

\section{Irodalom}

[1] Alfarawi, S., Webb-Martin, M., Mahmoud, S., Al-Dadah, R.K.: Thermal Analysis of Stirling Engine to Power Automotive Alternator Using Heat from Exhaust Gases, Energy Procedia 2014, 61:2395-2398. https://doi.org/10.1016/j.egypro.2014.12.013

[2] Ayaz, M., Mese, M.: A Permanent Magnet Alternator with Increased Power Capability for Hybrid Electric Vehicle Applications, Electric Power Systems Research 2016, 133:292-303. https://doi.org/10.1016/j.epsr.2015.12.035

[3] Radács, I.: Elektrotechnika-elektronika, www.tankonyvtar.hu., pp.: 202-226

[4] Kovács, I.: Generátor elemeinek és a pajzscsapágyán elhelyezkedő lefogató füleinek vizsgálata, Diplomaterv, Miskolc, 2015, pp.: 3-7 
[5] Taguchi, G.: System of experiment design, 1. Experimental design, UNIPUB, Kraus International Publications, White Plains, New York, (1984) p.:143

[6] Fridrik, L.: Válogatott fejezetek a gépgyártástechnológiai kísérletek tervezése témaköréből, Műszaki Könyvkiadó (1987), p.:109

[7] Starters E-Components and Generators Automotive generátor tesztkatalógus (2018) 0121 Y00 203 (bizalmas dokumentáció)

[8] Varga, Gy. Hepp, I.: A Talyrond 365 típusú köralak- és helyzethiba vizsgáló berendezés használatának kezdő lépései, Oktatási segédlet, Miskolc, (2013), pp.: 5-6 